\title{
Remuneration of the Defence Sector Employees in the Context of Legislative Changes
}

\author{
Monika DAVIDOVÁ, ${ }^{1}$ Alojz FLACHBART, ${ }^{2}$ Libor JÍLEK ${ }^{3}$
}

\begin{abstract}
This paper focuses on the remuneration of employees of the defence sector in the context of legislative changes. Its target are the periods between 1999-2006 and 30. 6. 2015-2007. In a chronological survey, there are indicated the legislative changes and related ministerial regulations.
\end{abstract}

Keywords: remuneration, legislation on employee remuneration, salary development

\section{Introduction}

Employee remuneration is based on a well-articulated philosophy - the system of beliefs and guiding principles that correspond to the organization values and help put them into practice. This philosophy recognizes that if the management of human resources is about investing in human capital, from which it demands an adequate, reasonable return, then it is okay to reward people differently according to their contribution and benefits. The remuneration strategies and processes that need to be implemented, must be based on a business strategy. Remuneration is implemented within the corporate wage policy. The salary and wage policy is based on the overall strategy of the company, its market position, development plans, economic situation of the company, organizational structure, technical parameters, production and on the result of an agreement with the social partners. In terms of outside influences, it must respect legal conditions, conjectural situation and the situation of the labour market.

\section{Remuneration in the Defence Sector}

The remuneration of various professional soldiers of the armed forces is specific, it depends on the specific tasks and goals of these institutions and their organisational structure. The issue of remuneration of professional soldiers in the Army of the Czech Republic (ACR) has always been, and still is, a hot topic. The professional soldiers (hereinafter VZP) in the ACR are rewarded on the base of existence of a single salary system in the Czech Republic (CR) [1] as employees of the state, just like the soldiers in Germany or the UK, but unlike other professional armed forces, their remuneration has not been based on a link between the pay system and career structure. [2]

1 Dipl. Eng., Ph.D., Faculty of Military Leadership, University of Defence, Brno; e-mail: monika.davidova@ unob.cz. She deals with the area of human resource management in Czech Armed Forces.

2 Dipl. Eng., Ph.D., Faculty of Military Leadership, University of Defence, Brno; e-mail: aloiz.flachbart@unob. cz. He deals with the area of financial resource management in Czech Armed Forces.

3 Dipl. Eng., Faculty of Military Leadership, University of Defence, Brno; e-mail: libor.jilek@unob.cz. He deals with the area of human resource management in Czech Armed Forces. 
The remuneration development in the defence sector in the period 1999-2015 can be divided into two periods, as follows:

- the first is in 1999-2006;

- the second is in 30. 6. 2015-2007.

\section{Development of Remuneration in the Ministry of Defence (MoD) in the period 1999-2006}

Throughout the period there was the basic Act 143/1992 Coll. On Salary and Remuneration for Work Readiness in Budgetary and Some Other Organizations and Bodies, as amended. [1] The Act had precisely defined what is considered to be a salary, on what charges and in what amount the employees are entitled (such as extra pay for work at night, on Saturdays and Sundays, public holidays, overtime and also pay for on-call). In Section 9 of the cited Act there are featured the amounts for rank premiums, including any amendments thereto.

This law was subsequently issued by the Government Regulation (NV) 79/1994 Coll. about the Emoluments of Staff of the Armed Forces, Security Forces and Services, Customs Administration, Members of the Congregation for Fire Protection, Employees of Certain Other Organizations, as amended. It regulated the provision of salaries of civil servants by determining the grade and so-called Salary scale, various bonuses and salary provision in other than the Czech currency. It included a catalogue of works and functions, according to which the private employees were classified in grades and steps. At that time there existed 12 grades, by educational attainment, which determined the catalogue of works for each function, and 12 steps according to the length of professional experience. The employee salary scale was then determined on the basis of qualifications and the number of years of professional (chargeable) practice. The salary scale was changed in the years 1999-2004 several times.

A specific example for better understanding: for the function-Chief of economic groups, including 10 grades, in 2000 the $6^{\text {th }}$ step salary scale was fixed at 9,750 CZK. Changed from

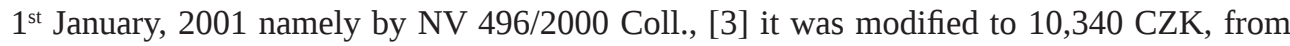
$1^{\text {st }}$ March, 2003 by NV 69/2002 Coll., [4] adjusted to 11,450 crowns and on the first of January 2004 by NV 584/2003 Coll., [5] adjusted to 11,990 CZK. The cited government regulation also considered the defining conditions for personal allowances, extra pay for leadership at all levels of management and command in the army, special bonuses, rewards and other pay.

On the basis of published standards in the Ministry of Defence there were also issued an internal standard order of the MoD 33/1994 Bulletin, Principles for Remuneration in the Ministry of Defence, which closely regulated the bonuses in the defence sector. On $1^{\text {st }}$ January, 2004, it came into effect NV 330/2003 Coll., On salaries of Employees in Public Services and Administration, as amended, which abolished the previous NV 79/1994 Coll. This normative dealt, like its predecessor, with the salary class, salary grade and pay fares, personal surcharge, additional fee for management, special bonuses, remuneration and other pay not only for VZP and civilian employees (hereinafter o. z.) of the MoD, but also for other employees in public services and administration. Part of this NV was not a catalogue of work since it also had come into effect on $1^{\text {st }}$ January, 2004, in NV 469/2002 Coll.

On a Catalogue of Jobs in Public Services and Administration, as amended (hereinafter NV 469/2002 Sb.), the salary scale underwent the most notable changes around the norm. 
The number of grades increased from 12 to 16, and due to many changes in the conditions for determining the amount of the salary rate, there was set up a 5-pay scale instead of one scale that had previously been applicable to all employees listed in NV 79/1994 Coll., For VZP of the MoD the amount of pay scales was determined in 2004 and 2005, according to Annex 4 NV 330/2003 Coll., and in 2006, according to Annex 3 of this normative act. The wage rates valid from $1^{\text {st }}$ January, 2004, increased by 4.1 percent, since $1^{\text {st }}$ January, 2005 there was a further increase of 7.0 percent. The wage rates valid from $1^{\text {st }}$ January, 2006 are presented in Appendix 1.

Table 1. The pay scale according to grades and degrees in effect since $1^{\text {st }}$ January, 2006 suppl. 3 NV 330/2003 Coll., where the first entry is the pay grade, the second the amount of years of creditable practice /until 1, 2, 4, 6, 9, 12, 15, 19, 23, 27, 32 and over 32 years, the next is the pay class. [8]

\begin{tabular}{|c|c|c|c|c|c|c|c|c|c|c|c|c|}
\hline 胥 & 1 & 2 & 3 & 4 & 5 & 6 & 7 & 8 & 9 & 10 & 11 & 12 \\
\hline 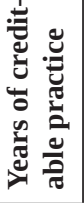 & 1 & 2 & 4 & 6 & 9 & 12 & 15 & 19 & 23 & 27 & 32 & $<32$ \\
\hline 1 & 7,080 & 7,290 & 7,500 & 7,710 & 7,940 & 8,170 & 8,420 & 8,660 & 8,940 & 9,210 & 9,490 & 9,790 \\
\hline 2 & 7,690 & 7,900 & 8,130 & 8,360 & 8,610 & 8,870 & 9,140 & 9,410 & 9,710 & 9,990 & 10,300 & 10,620 \\
\hline 3 & 8,340 & 8,570 & 8,820 & 9,090 & 9,340 & 9,620 & 9,910 & 10,210 & 10,530 & 10,850 & 11,180 & 11,530 \\
\hline 4 & 9,040 & 9,300 & 9,560 & 9,840 & 10,130 & 10,430 & 10,750 & 11,070 & 11,410 & 11,760 & 12,110 & 12,500 \\
\hline 5 & 9,820 & 10,090 & 10,380 & 10,680 & 11,000 & 11,320 & 11,660 & 12,020 & 12,380 & 12,760 & 13,150 & 13,570 \\
\hline 6 & 10,640 & 10,950 & 11,260 & 11,590 & 11,930 & 12,290 & 12,660 & 13,030 & 13,430 & 13,840 & 14,270 & 14,730 \\
\hline 7 & 11,540 & 11,890 & 12,230 & 12,580 & 12,950 & 13,340 & 13,740 & 14,160 & 14,580 & 15,030 & 15,490 & 15,970 \\
\hline 8 & 12,530 & 12,880 & 1,3250 & 13,640 & 14,070 & 14,460 & 14,900 & 15,340 & 15,800 & 16,300 & 16,810 & 17,320 \\
\hline 9 & 13,590 & 13,970 & 14,380 & 14,790 & 15 & 15,680 & 16,150 & 16,650 & 17,150 & 17,680 & 18,220 & 18,790 \\
\hline 10 & 14,740 & 15,170 & 15,590 & 16,050 & 16,530 & 17,010 & 17,520 & 18,060 & 18,610 & 19,180 & 19,770 & 20,390 \\
\hline 11 & 16,010 & 16,450 & 16,930 & 17,410 & 17,940 & 18,460 & 19,010 & 19,600 & 20,200 & 20,800 & 21,440 & 22,130 \\
\hline 12 & 17,350 & 17,850 & 18,360 & 18,900 & 19,450 & 20,020 & 20,630 & 21,250 & 21,900 & 22,570 & 23,270 & 24,000 \\
\hline 13 & 18,820 & 19,370 & 19,930 & 20,500 & 21,100 & 21,720 & 22,370 & 23,060 & 23,760 & 24,490 & 25,250 & 26,040 \\
\hline 14 & 20,420 & 21,010 & 21610 & 22,240 & 22,900 & 23,570 & 24,270 & 25,010 & 25,770 & 26,570 & 27,390 & 28,250 \\
\hline 15 & 22,160 & 22,790 & 23,440 & 24,130 & 24,840 & 25,580 & 26,340 & 27,130 & 27,970 & 28,830 & 29,720 & 30,640 \\
\hline 16 & 24,040 & 24,730 & 25,430 & 26,170 & 26,950 & 27,750 & 28,580 & 29,440 & 30,340 & 31,280 & 32,240 & 33,2 \\
\hline
\end{tabular}

Surcharges for leadership in this NV were changed only in specific amounts, but also in the statement of management positions related to these charges. The forementioned NV first determined that the employee is entitled to only one of the special allowances, which did not involve premium for work in difficult and unhealthy working conditions and premium for work performed alternately in the morning, afternoon and night shifts. The amount of the special benefit of the employee is determined by the employer within the range which, under certain conditions, is the best for the employee. For the employees of the MoD, the amount 
of special allowances specified in this normative did not change. Since $1^{\text {st }}$ January, 2004 other special allowances for VZP and o. z. were newly regulated by the order of MoD 48/2003 and the order of the MoD 49/2003, which were very extensive like the previous order of the MoD 33/1994, so this article does not describe them in detail.

From 1998, until the end of 2003, VZP had, in each half of the calendar year, another salary, if he worked at least 65 days with the same employer in the same service or employment. The amount of so-called " $13^{\text {th }}$ salary" was the sum of the amounts of salary, rank bonus, extra pay for leadership, personal bonus and a special bonus, with the exception of the premium for employee exposure within the unit of multinational forces outside the country. It was provided only as a half of the amount to which the employee would otherwise be entitled.

Since 2004, there was provided an additional pay in full, which was noticeable for VZP of MoD compared to the half of the amount in previous years, however, providing an additional salary was fully abolished to $1^{\text {st }}$ July, 2005. [6]

\section{Development of Remuneration in the Defence Sector in 30. 6. 2015-2007}

On $1^{\text {st }}$ January, 2007 the Act 262/2006 Coll., The Labour Code, [7] came into force, which caused a "revolution" in the pay gap in the defence sector. The Labour Code replaced the previously valid Act 65/1965 Coll., The Labour Code, as amended. The main reason for establishing the new Labour Code was that the original code was changed 43 times, and became progressively hard to read. The new Labour Code regulates the remuneration of all employees in employment, those receiving a wage or salary. That means that the MoD applies only this law to o. z., as the VZP are employees in service. Of course, during the years 2007-2012 the Labour Code underwent several changes, but the changes in the remuneration stayed almost untouched. The changes were related to the field of occupational safety and health, labour relations and compensation expenses provided to employees in connection with their work performance.

The remuneration of VZP is still, to date, engaged in Act 143/1992 Coll., which has been modified several times, but since 2007, it has been determined not only the remuneration of o. z. of Defence Department but by the Labour Code. These changes resulted in the cancellation of all previously existing $\mathrm{NV}$ and order of the MoD, relating to remuneration in the defence sector, namely NV 330/2003 Coll., order of the MoD 48/2003 Coll. and order of the MoD 49/2003 Coll. The issue of remuneration of VZP was recently dealt by NV 565/2006 Coll. On the Emoluments of Professional Soldiers, as amended (hereinafter NV 565/2006 Coll.) and order of the MoD 44/2006 Bulletin, Internal Salary Regulation for Professional Soldiers (hereinafter referred to as order of the MoD 44/2006). For o. z. came into effect NV 564/2006 Coll. On Salaries of Employees in Public Services and Administration, as amended (hereinafter NV 564/2006 Coll.) and order of the MoD 45/2006 Bulletin, Internal Salary Regulations for Civil Employees of the Ministry of Defence (hereinafter referred to as order of the MoD 45/2006).

However, since 2010 there is a valid, for the defence sector, so-called Collective agreement, which replaced order of the MoD 45/2006. This binding agreement governs the relations among the o. z., Ministry of Defence, the Czech-Moravian Confederation of Trade Unions of Civilian Employees of the Army, a Separate Union Association of Employees of 
the Ministry of Defence. It reflects mainly the working conditions of o. z. and their claims on employment, health and safety at work. The appendix deals with, among other things, the rewarding of staff, particularly special surcharges.

Apart from these norms, the remuneration in the defence sector in this period was also concerned by NV 469/2002 Coll., On the Catalogue of Jobs in Public Services and Administration, as amended, which was, from $1^{\text {st }}$ October, 2010 replaced by NV 222/2010 Coll., On the Catalogue of Jobs in Public Services and Administration, as amended. Furthermore, from $1^{\text {st }}$ January, 2011 came into effect the NV 223/2010 Coll., On the Catalogue of Works of Professional Soldiers, as amended, which means that the VZP, as the only public service employees, have their own catalogue of works.

As a result of the entry into force of the Labour Code, there was a significant limitation of the scope of the Act 143/1992 Coll., which, since 2007, regulates the provision of salaries and remuneration for work readiness only for the VZP. The contents of this law remained almost the same throughout the defined period. The only major change was the change in rank premiums from $1^{\text {st }}$ January, 2011, which was a response to the amendment of the Act 221/1999 Coll., On Professional Soldiers, as amended, which was also due to a significant change in the rank designation for the VZP. For comparison, there are mentioned in Table 2 the rank premiums valid until 31 ${ }^{\text {st }}$ December, 2010 and from $1^{\text {st }}$ January, 2011, including the changes in rank designation. From the table it is evident that not only the rank of Corps team, NCOs and sergeants, but also the rank premiums in all ranks corps underwent distinct changes. 
M. DAVIDOVÁ, A. FLACHBART, L. JÍLEK: Remuneration of the Defence Sector Employees...

Table 2. Rank surcharges for the VZP. [1: para 9]

\begin{tabular}{|l|c|l|c|}
\hline $\begin{array}{l}\text { Rank until } \\
\text { 31 }\end{array}$ December, 2010 & $\begin{array}{l}\text { Rank Surcharge } \\
\text { (in CZK monthly) }\end{array}$ & $\begin{array}{l}\text { Rank since } \\
\mathbf{1}^{\text {st }} \text { January, 2011 }\end{array}$ & $\begin{array}{l}\text { Rank Surcharge } \\
\text { (in CZK monthly) }\end{array}$ \\
\hline Private & 800 & & \\
\hline Staff Sergeant & 1,200 & Private First Class & 1,200 \\
\hline Sergeant & 1,300 & Corporal & 1,300 \\
\hline Sergeant Major & 1,400 & Sergeant & 1,400 \\
\hline $\begin{array}{l}\text { Company Sergeant } \\
\text { Major }\end{array}$ & 1,600 & Staff Sergeant & 1,600 \\
\hline Warrant & 1,800 & $\begin{array}{l}\text { Company Sergeant } \\
\text { Major }\end{array}$ & 2,000 \\
\hline $\begin{array}{l}\text { Warrant Officer Class } \\
\text { One }\end{array}$ & 1,900 & Warrant & 2,300 \\
\hline $\begin{array}{l}\text { Command } \\
\text { Sergeant Major }\end{array}$ & 2,000 & $\begin{array}{l}\text { Warrant Office Class } \\
\text { One }\end{array}$ & 2,600 \\
\hline Staff Sergeant & 2,200 & $\begin{array}{l}\text { Command Sergeant } \\
\text { Major }\end{array}$ & 3,100 \\
\hline Staff Sergeant Major & 2,400 & Start Sergeant Major & 3,700 \\
\hline Lieutenant & 2,600 & Lieutenant & 3,100 \\
\hline First lieutenant & 2,800 & First lieutenant & 3,300 \\
\hline Captain & 3,000 & Captain & 3,500 \\
\hline Major & 3,200 & Major & 3,700 \\
\hline Lieutenant colonel & 3,400 & Lieutenant colonel & 4,000 \\
\hline Colonel & 3,600 & Colonel & 4,300 \\
\hline Brigadier general & 3,900 & Brigadier general & 5,100 \\
\hline Major general & 4,100 & Major general & 6,800 \\
\hline Lieutenant general & 4,300 & Lieutenant general & \\
\hline Army general & 4,600 & Army general & \\
\hline & & & \\
\hline
\end{tabular}

The Government Regulation 565/2006 Coll., on Emoluments of Professional Soldiers, as amended, effective from $1^{\text {st }}$ January, 2007 is based on the Law 143/1992 Coll. and follows the structure of, at that time invalid, NV 330/2003 Coll., so it consequently deals with pay fares, personal surcharge, additional fee for leadership, extra pay for work in difficult environments, special bonuses and rewards, and, therefore, there are again described only the essential changes related to NV 565/2006 Coll.

The salary scale again passed through the biggest changes in the regulation of government. For almost all VZP are paid according to the pay scale set out in Annex 1 of this norm. From $1^{\text {st }}$ January, 2007, there was an increase in pay scales for the VZP up to $10 \%$. From $1^{\text {st }}$ June, 2009, there was implemented flat rate pay scales increase for VZP up by 3.5\%, but from $1^{\text {st }}$ January, 2011 the VZP wage rates for the first time in the history of the Czech Republic dropped by $10 \%$. The specific pay scale for VZP from $1^{\text {st }}$ January 2011, are shown in Table 3. 
M. DAVIDOVÁ, A. FLACHBART, L. JÍLEK: Remuneration of the Defence Sector Employees...

Table 3. Pay scale for VZP according to the pay classes and grades valid from 1st January, 2011 where the first item is the pay grade, the second-the sum of the years of eligible work experience until 1, 2, 4, 5, 6, 9, 12, 15, 19, 23, 27, 32 and over 32 years, the third-the pay class. [9]

\begin{tabular}{|c|c|c|c|c|c|c|c|c|c|c|c|c|}
\hline 胥 & 1 & 2 & 3 & 4 & 5 & 6 & 7 & 8 & 9 & 10 & 11 & 12 \\
\hline 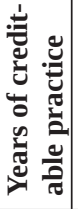 & 1 & 2 & 4 & 6 & 9 & 12 & 15 & 19 & 23 & 27 & 32 & $<32$ \\
\hline 1 & 6,680 & 6,930 & 7,190 & 7,460 & 7,750 & 8,050 & 8,360 & 8,670 & 9,000 & 9,350 & 9,700 & 10,070 \\
\hline 2 & 7,250 & 7,530 & 7,820 & 8,110 & 8,420 & 8,730 & 9,080 & 9,420 & 9,770 & 10,150 & 10,530 & 10,930 \\
\hline 3 & 7,860 & 8,160 & 8,460 & 8,800 & 9,130 & 9,470 & 9,830 & 10,210 & 10,600 & 11,000 & 11,420 & 11,850 \\
\hline 4 & 8,520 & 8,850 & 9,180 & 9,530 & 9,900 & 10,260 & 10,660 & 11,060 & 11,480 & 11,910 & 12,360 & 12,830 \\
\hline 5 & 9,250 & 9,610 & 9,970 & 10,350 & 10,740 & 11,150 & 11,570 & 12,010 & 12,460 & 12,940 & 13,430 & 13,950 \\
\hline 6 & 10,020 & 10,410 & 10,800 & 11,210 & 11,630 & 12,070 & 12,530 & 13,000 & 13,500 & 14,010 & 14,540 & 15,090 \\
\hline 7 & 10,870 & 11,280 & 11,700 & 12,150 & 12,610 & 13,090 & 13,580 & 14,090 & 14,620 & 15,170 & 15,750 & 16,350 \\
\hline 8 & 11,800 & 12,240 & 12,710 & 13,200 & 13,700 & 14,220 & 14,760 & 15,320 & 15,900 & 16,500 & 17,130 & 17,780 \\
\hline 9 & 12,800 & 13,280 & 13,780 & 14,310 & 14,850 & 15,400 & 16,000 & 16,600 & 17,220 & 17,880 & 18,550 & 19,260 \\
\hline 10 & 13,880 & 14,400 & 14,950 & 15,520 & 16,110 & 16,710 & 17,350 & 18,000 & 18,680 & 19,380 & 20,120 & 20,880 \\
\hline 11 & 15,080 & 15,650 & 16,250 & 16,860 & 17,490 & 18,160 & 18,840 & 19,550 & 20,290 & 21,060 & 21,850 & 22,680 \\
\hline 12 & 16,340 & 16,950 & 17,600 & 18,260 & 18,950 & 19,660 & 20,410 & 21,180 & 21,980 & 22,810 & 23,670 & 24,570 \\
\hline 13 & 17,720 & 18,390 & 19,080 & 19,800 & 20,550 & 21,330 & 22,130 & 22,960 & 23,830 & 24,730 & 25,660 & 26,640 \\
\hline 14 & 19,230 & 19,950 & 20,700 & 21,490 & 22,300 & 23,130 & 24,020 & 24,920 & 25,860 & 26,830 & 27,850 & 28,900 \\
\hline 15 & 20,870 & 21,660 & 22,480 & 23,320 & 24,200 & 25,110 & 26,060 & 27,050 & 28,080 & 29,140 & 30,240 & 31,370 \\
\hline 16 & 22,640 & 23,490 & 24,380 & 25,300 & 26,250 & 27,240 & 28,260 & 29,330 & 30,430 & 31,580 & 32,770 & 34,0 \\
\hline
\end{tabular}

The surcharges for guidance contained in this standard, which, compared with the previous NV 330/2003 Coll., were changed mainly in the number of management positions, which are entitled to them, because it deals only with the normative VZP. The NV 565/2006 Coll., newly do not assess a surcharge for work in difficult environments such as additional cost, so, since 2007, the VZP were paid regardless of the amount of the special allowances, if eligible. The surcharge of 400 to 1,400 CZK per month includes the VZP, if the exercise of the duties associated with difficulties arising from exposure to dangerous influence and measures to reduce or eliminate them. These include dust, chemical substances and mixtures, noise, vibration, biological agents that could endanger health, increasing pressure and radiation. The amount of this bonus is determined by the employer level of risk, intensity and the exposure times of their influence.

In the years 2007-2012 it was still in force, that to the VZP belongs only to one of the special allowances, and the highest, which can be claimed, in addition to the special premium for service performed alternately in the morning, afternoon and night shifts in the amount of 400 to 1,000 CZK. This newly did not apply for a special allowance in other than Czech 
currency in the amount of 700 to 4,000 per month, to which a VZP is entitled if included in the business unit of the multinational forces, or detached. The specific types and the amount of special allowances are given in Annex order of the MoD 44/2006.

The award, calculation of the individual components of salary, contributions to social and health insurance, including taxes on personal income, tax credits deductible, etc. were fundamentally the same for the VZP and even o. z. Another significant change in remuneration of VZP dates from $1^{\text {st }}$ July, 2015 when there came into force an amendment to Act 221/1999 Coll., On Professional Soldiers. This change is more closely described in another article.

\section{Conclusion}

The remuneration of employees is one of the tasks of human resources management in any organization. A properly set up system of evaluation and remuneration gives employees a healthy level of motivation. Remuneration is dependent on the economic aspects of the employer. Due to historical and social aspects, the salary policy is not left to market mechanisms. Through legislation, the state sets the minimum wage, salary conditions of employees of state and public administration.

Remuneration of employees of the defence sector is dependent on the specific tasks, objectives and organizational structure of the resort. For MoD, there were two pivotal periods: a) the period between 1999-2006, b) the period from 2007-30 June, 2015. For the first period, there was the basic Act 143/1992 Coll., on Salary and Remuneration for Work Readiness in Budgetary and Some Other Organizations and Bodies, as amended, for the second period-the amendment to Act 262/2006 Coll., Labour Code and related legislative changes to departmental regulations.

\section{References}

[1] Act 143/1992 Coll., On payment and Remuneration for Work Readiness in Budgetary and Some Other Organizations and bodies, as amended. In. Collection of Laws. Prague, 2010-2011. www.zakonyprolidi.cz/cs/1992-143. (Downloaded: 151 2017)

[2] PERNICA, B.: Ozbrojené síly ČR a otázka provázanosti platového a kariérního řádu (srovnávací studie). Vojenské rozhledy, 143 (2005), 71-80.

[3] Government Regulation 496/2000 Coll., Amending Government Regulation 79/1994 Coll., On Salaries of Employees in Armed Forces, Safety authorities, Board of customs, Fire protection.

[4] Government Regulation 69/2002 Coll., Amending Government Regulation 79/1994 Coll., On Salaries of Employees in Armed Forces, Safety authorities, Board of customs, Fire protection.

[5] Government Regulation 584/2003 Coll., Amending Government Regulation 79/1994 Coll., On Salaries of Employees in Armed Forces, Safety authorities, Board of customs, Fire protection.

[6] Government Regulation 213/2005 Coll., Amending Government Regulation 330/2003 Coll., On Salaries of Employees in Public service, as amended by the Government Regulation 637/2004 Coll., On the Catalogue of jobs and eligibilities. 
M. DAVIDOVÁ, A. FLACHBART, L. JÍLEK: Remuneration of the Defence Sector Employees...

[7] Act 262/2006 Coll., The Labour Code.

[8] Government Regulation 537/2005 Coll., Amending Government Regulation 330/2003 Coll., On salaries of Employees in Public Services and Administration, as amended. In. Collection of Laws. Prague, 14. 12. 2005, Annex 3. www.zakonyprolidi.cz/cs/2005-537 (Downloaded: 121 2017)

[9] Government Regulation 376/2010 Coll., Amending Government Regulation 565/2006 Coll., On Emoluments of Professional Soldiers, as amended. In. Collection of Laws. Prague, 7. 12. 2010, Annex 1. www.zakonyprolidi.cz/cs/2010-376. (Downloaded: 151 2017) 